\title{
Effect of Alcohols on the Production of Lytic Enzyme by a Bacterium Isolated from Coastal Waters
}

\author{
Isao Sugahara, ${ }^{*}$ Koichiro Hayashi, ${ }^{*}$ Toshio Kimura, ${ }^{*}$ Shigekazu YamanaKa, \\ Hiroyuki NiWA, ${ }^{*}$ and Nobuyoshi TANIOKA*
}

(Accepted November 4, 1983)

\begin{abstract}
The suppression of the production of lytic enzyme was investigated using alcohols as membranemodifying agents.

At the concentrations which growth was not suppressed, the production of lytic enzyme by strain $\mathrm{V} 37$ was inhibited by n-alcohols having a range of 8 to 14 carbon atoms, phenethyl alcohol and benzyl alcohol, respectively.

The formation of extracellular lytic enzyme by the cells from the lag phase to the early logarithmic phase of growth was most susceptible to membrane-modifying agents such as octanol and phenethyl alcohol.
\end{abstract}

The bacterium (named strain V 37) isolated from coastal regions extracellulary produced bacteriolytic enzyme when aerobically grown at $30^{\circ} \mathrm{C}$ in polypepton-yeast extract medium containing inorganic salt, such as $\mathrm{NaCl}, \mathrm{KCl}, \mathrm{NaSCN}, \mathrm{Na}_{2} \mathrm{SO}_{4}$ and $\mathrm{K}_{2} \mathrm{SO}_{4}{ }^{1,2)}$ Strain $\mathrm{V} 37$ grew well in the medium without added any inorganic salt, but could not produce bacteriolytic enzyme." ${ }^{1}$ Among inorganic salts tested, $\mathrm{NaCl}$ or $\mathrm{KCl}$ was most effective for the production of extracellular lytic enzyme, ${ }^{12}$ whereas the release of lytic enzyme from strain $\mathrm{V}$ 37 cells was not stimulated by $\mathrm{NaCl}$ and $\mathrm{KCl}$, respectively. ${ }^{3,4)}$

FisHMAN et al..$^{5)}$ indicated that a variety of alcohols and anesthetics selectively suppressed the formation of exoenzymes produced by various bacterial strains under conditions that allow normal growth.

In order to demonstrate the subcellular location of the enzyme formation, alcohols as membranemodifying agents were used in this study. This paper deals with the effect of alcohols on the production of bacteriolytic enzyme by strain V 37 .

\section{Methods}

Culture of Strain V 37 Capable of Producing Lytic Enzyme

The medium used in this study was composed of polypepton (Daigo Eiyō Kagaku), $10.0 \mathrm{~g}$ : yeast extract (Nakarai Chemicals), $5.0 \mathrm{~g}: \mathrm{NaCl}, 0.5 \mathrm{~mol}$ : varying amounts of alcohol to be tested and
$1,000 \mathrm{~m} l$ distilled water. The $\mathrm{pH}$ of the medium was adjusted to 7.0. The liquid medium was dispensed in $250 \mathrm{~m} l$ portions into $500 \mathrm{~m} l$ Sakaguchi flasks. Sterilization was done by means of autoclaving at $121^{\circ} \mathrm{C}$ for $15 \mathrm{~min}$, except for alcohol component. Alcohol component was added aseptically into the sterile medium. The Sakaguchi flask containing $250 \mathrm{~m} l$ of the preculture medium without added any alcohol was inoculated with a loopful of strain $\mathrm{V} \mathrm{37}$, and incubated at $30^{\circ} \mathrm{C}$ for $24 \mathrm{~h}$ on reciprocating shaker with a shaking rate of 100 strokes per min. The flasks containing $250 \mathrm{ml}$ of the medium added varying amounts of alcohol respectively were inoculated with each $1.0 \mathrm{ml}$ of strain V 37 culture fluids from the preculture medium. The inoculated flasks were incubated at $30^{\circ} \mathrm{C}$ for $24 \mathrm{~h}$ on reciprocating shaker. The culture fluids were withdrawn at fixed intervals of time, and then the cells were removed by centrifugation at $13,000 \times g$ for $20 \mathrm{~min}$. The culture supernatant obtained was dialysed against distilled water at $5^{\circ} \mathrm{C}$ for $3 \mathrm{~h}$. The dialysate of the culture supernatant was used for the assay of bacteriolytic activity.

\section{Assay of Lytic Activity}

Lysis of bacterial suspension was estimated by following the change in optical density at $570 \mathrm{~nm}$ $\left(\mathrm{OD}_{570}\right)$ in a Shimazu Spectronic 20 spectrophotometer. The reaction mixture for the assay of lytic activity was as follows: heat-killed cell suspension of Micrococcus luteus $1.0 \mathrm{ml}, 0.05 \mathrm{M}$ Tris- $\mathrm{HCl}$

* Faculty of Fisheries, Mie University, Tsu 514, Japan（营原 席・林 孝市郎・木村俊夫・山中重和・丹羽 㤵之・谷岡信良: 三喠大学水産学部). 
buffer $(\mathrm{pH} 7.0) 1.0 \mathrm{~m} l$ and dialysate of the culture supernatant or sonicated cell suspension $1.0 \mathrm{~m} l$. The assay was carried out for $30 \mathrm{~min}$ at $40^{\circ} \mathrm{C}$, and the optical density $\left(O D_{6 r 0}\right)$ of the reaction

Table 1. Effect of alcohols on the lytic activity of strain V 37

\begin{tabular}{|c|c|c|}
\hline Alcohols & Concentration & $\begin{array}{l}\text { Remaining } \\
\text { lytic activity }\end{array}$ \\
\hline None & & $100.0 \%$ \\
\hline Octanol & $0.0065 \%(\mathrm{v} / \mathrm{v})$ & 102.0 \\
\hline Decanol & $0.00083 \%(v / v)$ & 102.0 \\
\hline Dodecanol & $0.00024 \%(\mathrm{v} / \mathrm{v})$ & 104.9 \\
\hline Tetradecanol & $0.00048 \%(\mathrm{w} / \mathrm{v})$ & 102.9 \\
\hline Hexadecanol & $0.024 \%(\mathrm{w} / \mathrm{v})$ & 95.7 \\
\hline Phenethyl alcohol & $0.20 \%(w / v)$ & 97.2 \\
\hline Benzyl alcohol & $0.20 \%(w / v)$ & 100.6 \\
\hline
\end{tabular}

mixture was determined at fixed intervals of time Lytic activity was represented as a decrease ir $\mathrm{OD}_{5 r 0}$ per $1.0 \mathrm{~m} l$ of culture fluids for $30 \mathrm{~min}$.

\section{Lytic Activity Associated with Strain V 37 Cells}

Strain V 37 cells, harvested by centrifugation,

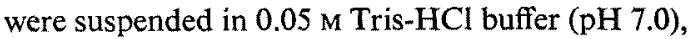
and sonically treated for $4 \mathrm{~min}$ at $0^{\circ} \mathrm{C}$ with a sonicator (Ultrasonics W-375). After removing the cell debris by centrifugation, lytic activity of the supernatant was determined.

\section{Results and Discussion}

Effect of Alcohols on the Lytic Activity

As shown in Table 1, all alcohols used in this study did not inhibit lytic activity of strain V 37.

Table 2. Effect of alcohols on the production of lytic enzyme by strain V37

\begin{tabular}{|c|c|c|c|}
\hline Alcohols & Concentration & $\begin{array}{r}\text { Growth } \\
(\% 0\end{array}$ & $\begin{array}{l}\text { Production of } \\
\text { lytic enzyme } \\
\text { con(rol) }\end{array}$ \\
\hline \multirow{7}{*}{ Octanol } & $0.0001 \%(v / v)$ & 101.7 & 104.0 \\
\hline & 0.0010 & 117.0 & 136.9 \\
\hline & 0.0030 & 132.5 & 109.2 \\
\hline & 0.0040 & 132.8 & 88.8 \\
\hline & 0.0050 & 111.8 & 49.5 \\
\hline & 0.0055 & 98.7 & 25.9 \\
\hline & 0.0072 & 87.2 & 14.7 \\
\hline \multirow{7}{*}{ Decanol } & $0.00010 \%(\mathrm{v} / \mathrm{v})$ & 107.3 & 110.8 \\
\hline & 0.00050 & 95.2 & 41.5 \\
\hline & 0.00060 & 93.2 & 56.9 \\
\hline & 0.00065 & 83.7 & 41.5 \\
\hline & 0.00070 & 69.5 & 20.9 \\
\hline & 0.00100 & 3.1 & 11.1 \\
\hline & 0.00200 & 0 & 0 \\
\hline \multirow{5}{*}{ Dodecanol } & $0.00001 \%(\mathrm{v} / \mathrm{v})$ & 93.1 & 94.9 \\
\hline & 0.00010 & 99.5 & 52.4 \\
\hline & 0.00015 & 100.2 & 47.0 \\
\hline & 0.00020 & 81.5 & 32.8 \\
\hline & 0.00030 & 0 & 0 \\
\hline \multirow{4}{*}{ Tetradecanol } & $0.0002 \%(\mathrm{w} / \mathrm{v})$ & 81.9 & 41.8 \\
\hline & 0.0003 & 73.7 & 40.7 \\
\hline & 0.0004 & 80.9 & 35.5 \\
\hline & 0.0007 & 23.0 & 23.0 \\
\hline \multirow{3}{*}{ Hexadecanol } & $0.005 \%(w / v)$ & 74.8 & 78.1 \\
\hline & 0.010 & 91.1 & 91.2 \\
\hline & 0.020 & 83.3 & 81.2 \\
\hline \multirow{3}{*}{ Phenethyl alcohol } & $0.10 \%(w / v)$ & 98.7 & 32.6 \\
\hline & 0.20 & 95.3 & 5.9 \\
\hline & 0.25 & 69.6 & 3.0 \\
\hline \multirow[t]{2}{*}{ Benzyl alcohol } & $\%(w / v)$ & 99.6 & 9.5 \\
\hline & 0.25 & 100.9 & 11.9 \\
\hline
\end{tabular}


Effect of Alcohols on the Production of Lytic Enzyme

Fishiman et al. ${ }^{5)}$ reported that aliphatic alcohols selectively suppressed the production of penicillinase by Bacillus licheniformis. EuIASz et al. ${ }^{\text {b) }}$ also described that n-alcohols caused a shift in transition temperature of model membrane systems. These facts indicate that the production of exoenzyme was influenced by the changes in membrane organization.

As shown in Table 2, the suppression of lytic enzyme formation by $n$-alcohols ranging from 8 to 14 carbon atoms was observed in strain V 37 . However, hexadecanol did not exhibit significant inhibitory effect on the production of lytic enzyme by strain V 37 .

Phenethyl alcohol is known to inhibit the synthesis of unsaturated fatty acids in Escherichia coli. ${ }^{7}$ Both phenethyl alcohol and benzyl alcohol caused a broadening of the main lipid transition temperature. ${ }^{\theta)}$ Phenethyl alcohol exerts its effect on the penicillinase formation of Bacillus licheniformis by changes in the physical state of membrane lipids rather than by interference with the synthesis of unsaturated fatty acids. ${ }^{8)}$

As shown in Table 2, phenethyl alcohol and benzyl alcohol were found to inhibit significantly the production of lytic enzyme by strain $V 37$.
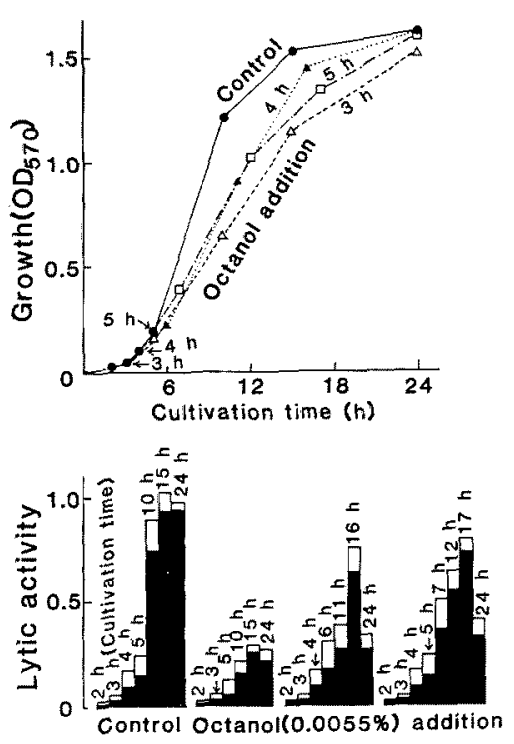

Fig. 1. Effect of octanol addition on the production of lytic enzyme during the growth of strain V 37. Each arrow indicates the cultivation time when octanol was added into the medium.

Lytic enzyme in the culture supernatant $(\boldsymbol{\omega})$, Lytic enzyme associated with strain $\vee 37$ cells $(\square)$.
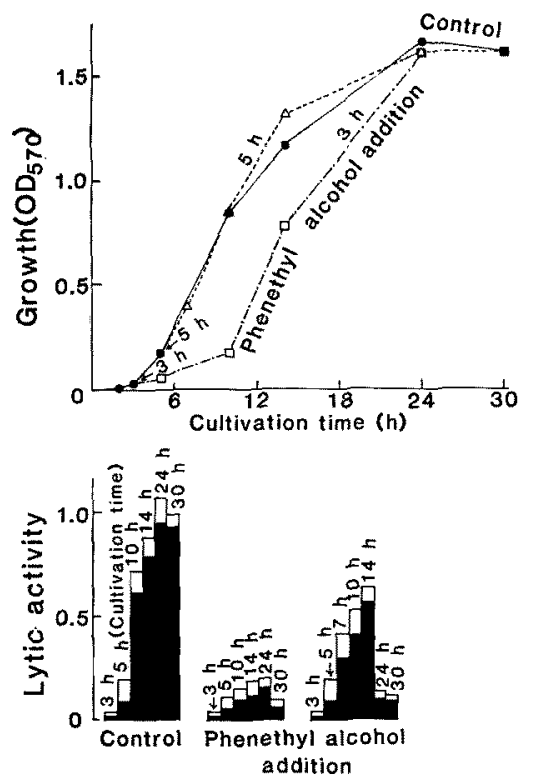

Fig. 2. Effect of phenethyl alcohol addition on the production of lytic enzyme during the growth of strain $\mathrm{V} 37$.

Each arrow indicates the cultivation time when phenethyl alcohol was added into the medium.

Lytic enzyme in the culture supernatant (W).

Lytic enzyme associated with strain V 37 cells (־).

Effect of Alcohol Addition on the Production of Lytic Enzyme during the Growth of Strain V 37

As shown in Figs. 1 and 2, the production of lytic enzyme was suppressed by the addition of octanol $(0.0055 \%)$ and phenethyl alcohol $(0.20 \%)$ respectively into the culture medium after $3 \mathrm{~h}$ of cultivation. However, the suppression of the enzyme formation was not complete when octanol or phenethyl alcohol was added into the culture medium after $4-5 \mathrm{~h}$ of cultivation. The formation of lytic enzyme by the cells from the lag phase to the early logarithmic phase of growth seemed to be most susceptible to membrane-modifying agents such as octanol and phenethyl alcohol.

\section{References}

1) I. Sugahara, K. Hayashi, T. Kimura, Y. Suzuki, H. Toyoda, and A. Matsuoka: Bull. Fac. Fish., Mie Univ., 7, 9-27 (1980).

2) I. Sugahara, K. Hayashi, T. Kimura, A. Matsuoka, C. JinNo, and S. Yamanaka: Bull. Fac. Fish., Mie Univ, 8, 49-60 (1981).

3) I. Sugahara, K. Hayashi, T. Kimura, and A. Matsuoka: Bull. Fac. Fish., Mie Univ., 8, 6171 (1981). 
4) I. Sugahara, K. Hayashi, T. Kimura, and C. JINNo: Bull. Fac. Fish., Mie Univ., 10, 25-32 (1983).

5) Y. Fishman, S. Rottem, and N. Citri: $J$. Bacteriol., 141, 1435-1438 (1980).

6) A. W. Eliasz, D. Chapman, and D. F. Ewing:
Biochim. Biophys. Acta, 448, 220-230 (1976).

7) W. D. NunN: Biochemistry, 16, 1077-1081 (1977).

8) Y. Fishman, S. Rottem, and N. Crtri: J. Bacteriol., 134, 434-439 (1978). 